\title{
The Periodontal Index
}

\author{
BY A. L. RUSSELL*
}

INSOFAR as the word "clinical" connotes therapy or treatment, a discussion of the Periodontal Index (PI) is out of place in a conference on clinical methods. PI is an epidemiological tool. The unit of study in epidemiology is the population, and not the individual. This leads to methods and procedures which would be inappropriate in diagnosis for the individual dental patient, but which are useful and valid in the field.

The rationale of some of these methods can be illustrated with data originally published by Sandler and Stahl.10 These data are shown here as Figure 1. This material was gathered in an effort to decide whether an estimate of gingival recession, tabulated as the percent per person of teeth with gingival recession exposing cementum, might be a useful adjunct in periodontal diagnosis. To this end the investigators compared individual gingival recession scores with individual scores for bone loss, computed from a full-mouth x-ray survey. They concluded, quite correctly, that an estimate of recession was unreliable in diagnosis of the individual patient; this in view of large numbers of individuals with high recession scores accompanied by minimal bone loss, and the large numbers of individuals with low recession scores and substantial bone loss. But it will be seen at once that the average degree of bone loss for a given degree of recession is quite constant, as shown by the regression lines in Figure 1. The average degree of bone loss for the entire group could have been computed from the average recession score with a high degree of precision. In appraising the status of the whole group, in short, the recession score would have been quite as valid and meaningful as the data from the more complex and costly $\mathrm{x}$-ray examination. The recession

*School of Public Health and School of Dentistry, University of Michigan.

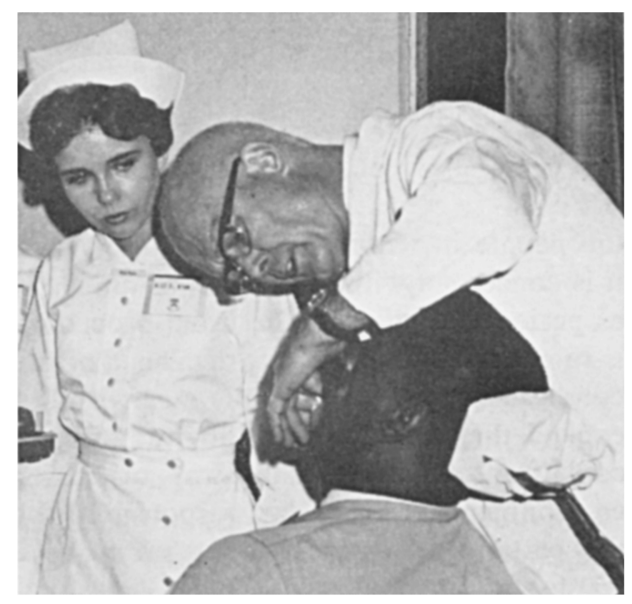

A. L. Russell examining.

score has been used extensively in the series of overseas nutrition surveys carried out by the Interdepartmental Committee on Nutrition for National Defense ${ }^{6}$ and was employed with the group of examinees seen here yesterday.

Another analogy might make the point more clearly. No single determination of blood cholesterol is adequate to determine

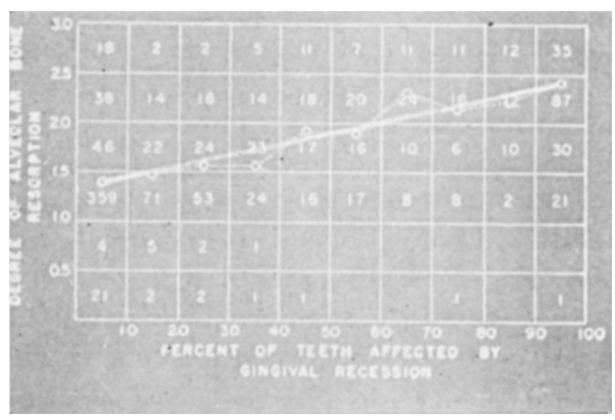

Fig. 1. Relation between gingival recession and alveolar bone loss (Sandler and Stahl).

Page 13/585 
the status of an individual patient. Nonetheless, the average value of blood cholesterol for each of you, taken once this morning, would be completely valid as an indication of the status of this group as a whole. No better group estimate would be gained by the analysis of two, four, six, or ten additional blood samples per person.

Field epidemiology is, in fact, not so much the study of disease as disease, as it is the study of the group characteristics of the people in whom disease occurs. When it is concerned with conditions as universal as periodontal disease, the usual procedure is to establish the relative prevalence of the condition by relatively simple means and to expend the principal effort in study of the concurrent factors-in the way of life or environment-which are responsible for the patterns of disease in the group as a whole.

The Periodontal Index was developed, over a trial period of ten years, to function in this situation.

PI criteria are shown in Table $1 .^{4}$ They are based upon the signs of periodontitis and the sequence in which they usually appear-inflammation, pocket formation, and loss of function. Each tooth is scored; the scores are totalled; and this total is divided by the number of teeth present. This score for the individual patient represents the average condition of the teeth in his mouth, as appraised in this manner.

These numbers would be meaningless, of course, unless they had some systematic relationship to clinical condition or prognosis on treatment. Table 2 illustrates the relationship between clinical diagnoses made for purposes of treatment planning in the Clinical Center Dental Clinic, National Institutes of Health, and PI scores for the same patients. A minimal gingivitis might be found in individuals considered negative on the PI scale; these usually scored from zero to .1 or .2. Those with significant gingivitis ranging upward toward incipient
TABLE 1

Scoring and Criteria for the Periodontal Index

\begin{tabular}{|c|c|}
\hline core & Criteria \\
\hline 0 & $\begin{array}{l}\text { Negative. There is neither overt inflam- } \\
\text { mation in the investing tissues nor loss of } \\
\text { function due to destruction of supporting } \\
\text { tissue. }\end{array}$ \\
\hline 1 & $\begin{array}{l}\text { Mild gingivitis. There is an overt area of } \\
\text { inflammation in the free gingivae which } \\
\text { does not circumscribe the tooth. }\end{array}$ \\
\hline 2 & $\begin{array}{l}\text { Gingivitis. Inflammation completely cir- } \\
\text { cumscribes the tooth, but there is no ap- } \\
\text { parent break in the epithelial attachment. }\end{array}$ \\
\hline 6 & $\begin{array}{l}\text { Gingivitis with pocket formation. The } \\
\text { epithelial attachment has been broken } \\
\text { and there is a pocket (not merely a deep- } \\
\text { ened gingival crevice due to swelling in } \\
\text { the free gingivae). There is no interfer- } \\
\text { ence with normal masticatory function, } \\
\text { the tooth is firm in its socket, and has not } \\
\text { drifted. }\end{array}$ \\
\hline 8 & $\begin{array}{l}\text { Advanced destruction with loss of mas- } \\
\text { ticatory function. The tooth may be } \\
\text { loose; may have drifted; may sound dull } \\
\text { on percussion with a metallic instrument; } \\
\text { may be depressible in its socket. }\end{array}$ \\
\hline
\end{tabular}

destructive disease usually scored in the range of .5 to 1.9 ; those with franklyestablished destructive disease, from 1.5 to 5.0; and those with disease in terminal stages from about 4.0 to 8.0 , the maximum score.

TABLE 2

Mouth Condition and Periodontal Scores

\begin{tabular}{lr}
\hline \multicolumn{1}{c}{ Most People with } & $\begin{array}{r}\text { Score in the } \\
\text { Range of }\end{array}$ \\
\hline $\begin{array}{l}\text { Clinically normal supportive } \\
\text { tissues }\end{array}$ & $\begin{array}{r}\text { zero to } .2 \\
.3 \text { to } .9 \\
\text { Simple gingivitis }\end{array}$ \\
$\begin{array}{l}\text { Beginning destructive periodontal } \\
\text { disease }\end{array}$ & .7 to 1.9 \\
$\begin{array}{l}\text { Established destructive periodontal } \\
\text { disease }\end{array}$ & 1.6 to 5.0 \\
Terminal disease & 3.8 to 8.0 \\
\hline
\end{tabular}

Practicability. The index has proved to be wide enough in scale to discriminate adequately between groups in Asia and Africa with high levels of prevalence and severity of disease, and simple enough to be practicable under a wide variety of field 


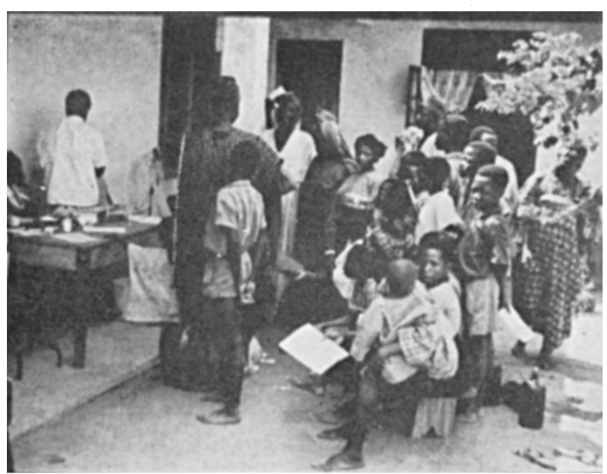

Fig. 2. Examination site in Osegere, Nigeria.

conditions. Figures 2 and 3 are illustrations of some of the situations in which examinations have been conducted. Figure 2 shows the examination in progress in Osegere, in western Nigeria, and Figure 3 the examination room and instruments in Sarrin, in the Beka'a Valley in Lebanon. As was the common experience, electric power was unavailable in either of these locations, though Sarrin had walking water -water that walked into the village on the heads of women from a source about three miles away.

The relative prevalences of periodontal diseases elicited in this series of international surveys 6 are illustrated in Figure 4. This table shows PI scores for a series of civilian populations aged 40-49 years, all surveyed by examiners of a single research organization.* The differences, in consequence, are true differences and not mere artifacts due to examiner disagreement. This decade of age, from 40 through 49 years, is particularly useful for study because these individuals are old enough that signs of periodontal disease are clearly evident, but not so old as to be mainly edentulous.

The differences in PI scores in this array are on the order of thirty-fold.

*The Epidemiology and Biometry Branch, National Institute of Dental Research, National Institutes of Health.

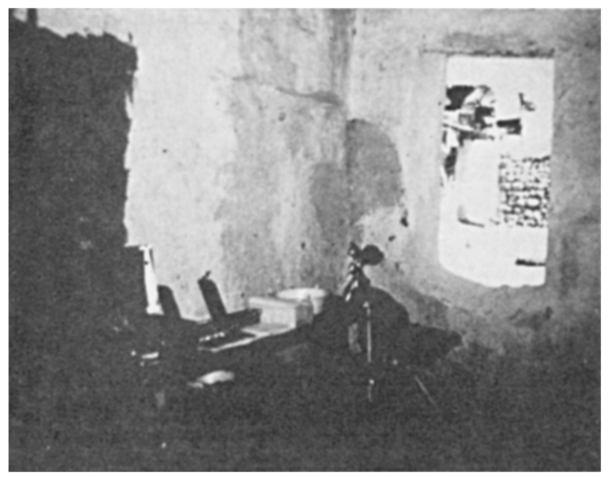

Fig. 3. Examination site in Sarrin, Lebanon.

The figure also illustrates one of the disadvantages common to indices of this sort - the fact that such scores are abstractions and relatively meaningless, unless one is familiar with conditions they are intended to assess. This is just as true, for example, of the Dow-Jones index or the index of freight car loadings as it is of PI or DMF.

Some concept of the range of scores shown in Figure 4 may be had through

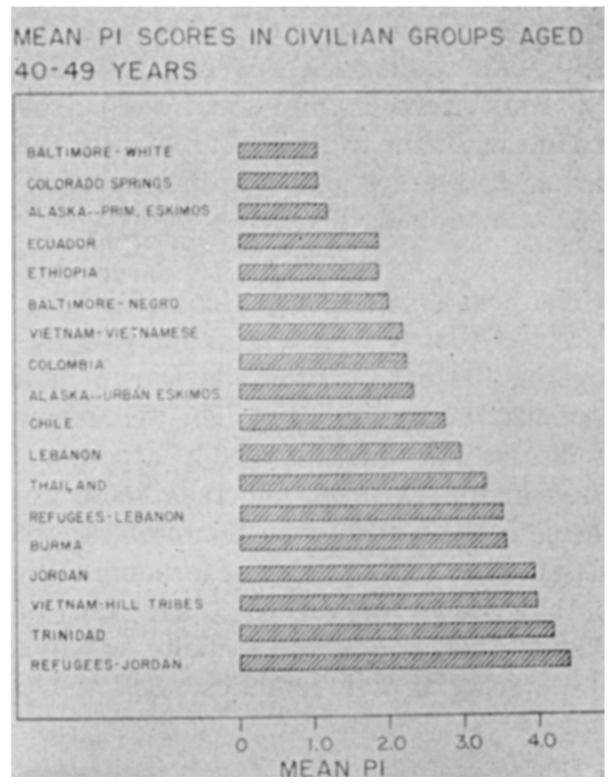

Fig. 4. PI scores for groups of civilians aged 40-49 years, examined by members of a single research organization. 


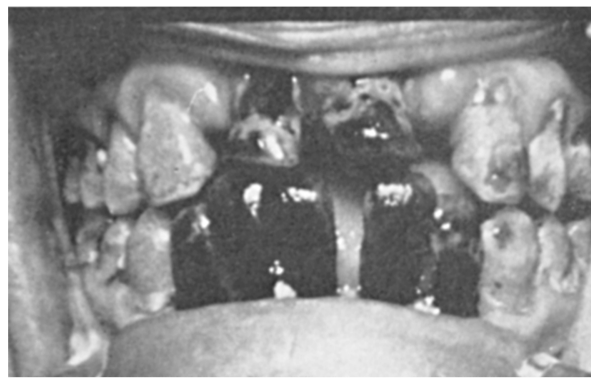

Fig. 5. Typical periodontal condition of hill tribesmen aged 40-49 years, South Vietnam.

study of the following illustrations. Figure 5 shows the periodontal condition of a 40-year-old woman examined in the hill country of Viet Nam; she was fairly typical of her cohorts at that age. The next illustration (Fig. 6) is representative of 40-yearold Vietnamese living in the delta areas. It will be noted that a mandibular incisor has already been lost to periodontal disease. The actual patient here was a boy of 17 years. The next illustration (Fig. 7) represents the average condition of white individuals aged 40-49 years in Baltimore, or in Eskimos the same age living in relatively remote areas of Alaska. This average, however, misrepresents the true state of things in Baltimore because most of the individuals studied there were better than the group average. Only about one person in nine in Baltimore scored as high as the median or average person in the four Vietnamese mountain villages. ${ }^{9}$

The next illustration in this series (Fig. 8) shows a fairly typical mouth in Osegere, Nigeria, the examination site shown in a previous illustration (Fig. 2).1 Extremes of disease like this are readily accommodated in the PI scale, and their mere existence is the reason why PI examiners are instructed to look quickly at a mouth such as that shown in Figure 9 and say, in effect, "This mouth is essentially negative on our scale of periodontal disease."

The group examined here yesterday is difficult to orient to these world-wide findings. Score distributions were pathological.

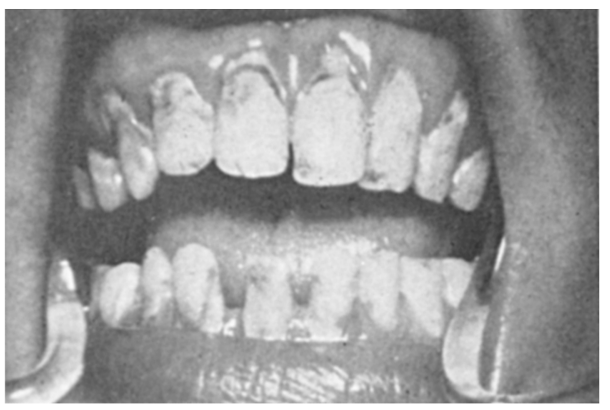

Fig. 6. Typical periodontal condition of South Vietnamese aged $40-49$ years.

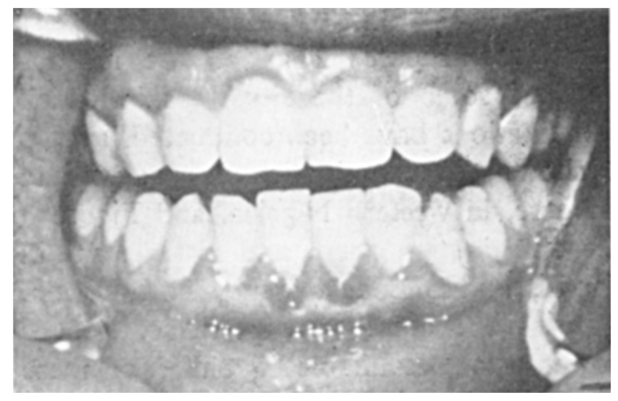

Fig. 7. Condition illustrating average PI score of Baltimore residents aged $40-49$ years.

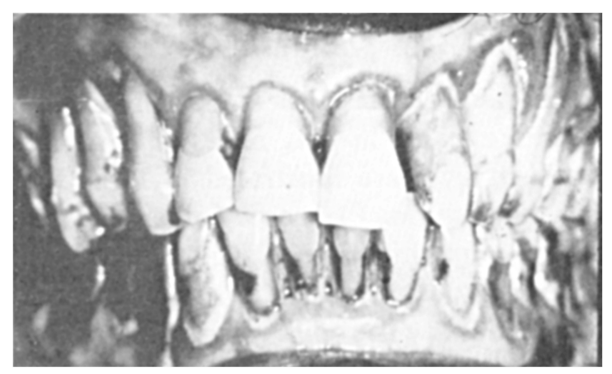

Fig. 8. Typical periodontal condition of Yoruba adults, Western Nigeria.

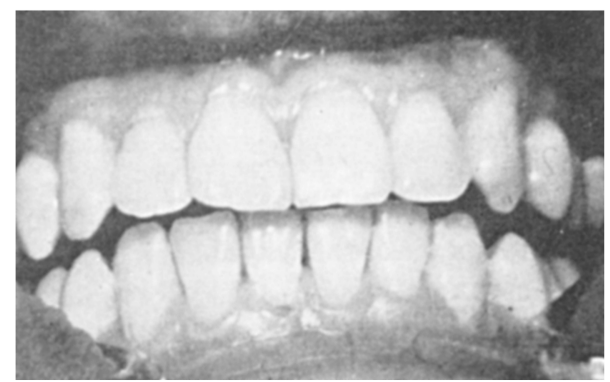

Fig. 9. Mouth essentially negative on the PI scale. 
There was obvious selection into two groups - good and bad. Young men in the sample scored far and away better than young men the nation over; far and away better, in fact, than young women in the sample, which is unusual and surprising. In the older age groups there was rather more disease than we would expect to find in a sample from the general United States population.

Population findings. But PI is used not so much in the study of disease as disease as it is used to establish a basis for study of the characteristics of the people in whom disease occurs.

One of the first findings in field studies of periodontal disease was the fact that in the United States, disease tends to be the more widespread and severe in persons of the less favorable socioeconomic status. This general tendency is illustrated in Table 3 , an array of PI scores for persons examined in Birmingham in 1957.8 There is a clear association between PI scores and something which is indicated by educational attainment. This is association, not causation; I am sure that nobody ever cured a case of periodontitis by going back to graduate school. But findings such as this point toward a factor in disease which seemed to call for further investigation. That factor might have been nutrition; this consideration led us to participation in the international nutrition surveys which have been described elsewhere. ${ }^{5}$

TABLE 3

Education and Periodontal Disease (Birmingham, 1957)

\begin{tabular}{|c|c|c|}
\hline \multirow[b]{2}{*}{ Persons with } & \multicolumn{2}{|c|}{$\begin{array}{c}\text { Average } \\
\text { Periodontal } \\
\text { Scores for }\end{array}$} \\
\hline & White & Negro \\
\hline 8 years of school or less & 1.42 & 2.18 \\
\hline 9 to 11 years of school & .93 & 1.09 \\
\hline 12 years of school & .52 & .80 \\
\hline 13 years of school or more & .29 & .41 \\
\hline
\end{tabular}

Table 4 shows some findings from one of these surveys and illustrates another method for the analysis of the relation between PI findings and a concomitant variable. In this instance, PI data have been used to divide a population group into a trichotomy of those with essentially normal tissues, those with gingivitis only, and those with advanced destructive periodontal disease as evidenced by pocketing or loss of mobility. In these Eskimo men, there was no difference in average levels of serum vitamin $\mathrm{A}$ between men in whatever group at whatever age. Much the same result was had when the analysis was made of average levels of serum ascorbic acid, as shown in Table 5. These findings were typical of the series; there was no consistent or significant pattern of association between these and other nutrients, an observation which sets up a rather formidable inference that vitamin $\mathrm{A}$ or $\mathrm{C}$ nutrition is not a major factor in adult periodontal disease.

TABLE 4

Serum Vitamin A (in mcg. $/ 100 \mathrm{ml}$ ): Alaska Scouts, 1958

\begin{tabular}{lccc}
\hline & $\begin{array}{c}\text { Ages } \\
\text { to }\end{array}$ & $\begin{array}{c}\text { Ages } \\
\text { Periodontal Condition }\end{array}$ & $\begin{array}{c}\text { Ages } \\
35\end{array}$ \\
\hline over \\
\hline $\begin{array}{l}\text { Normal gingival tissues } \\
\begin{array}{l}\text { Gingivitis only, without } \\
\text { pocket formation }\end{array}\end{array}$ & 36.8 & 35.4 & 33.1 \\
$\begin{array}{l}\text { With advanced destruc- } \\
\text { tive periodontal } \\
\text { disease }\end{array}$ & 38.6 & 35.2 & 34.3 \\
\hline
\end{tabular}

TABLE 5

Serum Vitamin C (in mg./100 ml): Alaska Scouts, 1958

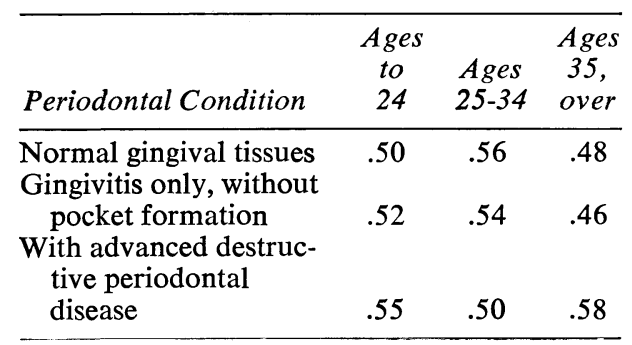


TABLE 6

Relation of Age, Sex and Oral Hygiene to PI Scores, 752 South Vietnamese Aged 15 Years or Older

\begin{tabular}{|c|c|c|c|}
\hline \multirow[b]{2}{*}{$\begin{array}{l}\text { Source of } \\
\text { Variation }\end{array}$} & \multicolumn{3}{|c|}{ Analysis of Variance } \\
\hline & $\begin{array}{l}\text { Degrees } \\
\text { of } \\
\text { Freedom }\end{array}$ & $\begin{array}{l}\text { Sum of } \\
\text { Squares }\end{array}$ & $\begin{array}{l}\text { Mean } \\
\text { Square }\end{array}$ \\
\hline $\begin{array}{l}\text { Multiple } \\
\text { regression }\end{array}$ & 3 & 1987.3188 & 662.4396 \\
\hline $\begin{array}{l}\text { Random } \\
\text { variation }\end{array}$ & 748 & 1000.6812 & 1.3378 \\
\hline $\begin{array}{l}F=495.2 \\
\text { Coefficient o }\end{array}$ & $\begin{array}{c}751 \\
\text { P: less th } \\
\text { multiple c }\end{array}$ & $\begin{array}{l}2988.0000 \\
\text { han } .001 \\
\text { correlation: }\end{array}$ & $=.82$ \\
\hline
\end{tabular}

Two concomitant factors, however, were consistently and strongly associated with disease. These were the age of the group and its state of oral hygiene. Group hygiene status was usually estimated by means of the OHI-S index of Greene and Vermillion, ${ }^{2}$ an index to be discussed later this morning by Dr. Greene. A finding typical for the series as a whole is shown in Table 6 , based on examinations of 752 Vietnamese 15 years of age or older. ${ }^{9}$ The small value for the error term in the table suggests that the two participating examiners were highly comparable, and that factors completely independent of age, sex, and oral hygiene could have had little effect upon PI scores. The multiple correlation accounts for about two-thirds of the variance. Of the variance explained, about 68 percent was attributable to hygiene and

TABLE 7

Relation of Age, Nutrition, and Oral Hygiene to Periodontal Scores, South Vietnam

\begin{tabular}{|c|c|c|c|}
\hline $\begin{array}{l}\text { Source of } \\
\text { Variation }\end{array}$ & $\begin{array}{c}\text { Analysis of } \\
\text { Degrees } \\
\text { of } \\
\text { Freedom }\end{array}$ & $\begin{array}{l}\text { Variance } \\
\text { Sum of } \\
\text { Squares }\end{array}$ & $\begin{array}{l}\text { Mean } \\
\text { Square }\end{array}$ \\
\hline $\begin{array}{l}\text { Multiple } \\
\text { regression } \\
\text { Random } \\
\text { variation }\end{array}$ & $\begin{array}{l}14 \\
75\end{array}$ & $\begin{array}{l}718.3050 \\
331.6950\end{array}$ & $\begin{array}{r}51.3075 \\
4.4226\end{array}$ \\
\hline $\begin{array}{l}F=11.6012 \\
\text { Coefficient of }\end{array}$ & $\begin{array}{l}89 \\
\mathrm{P}:< \\
\text { multiple cc }\end{array}$ & $\begin{array}{l}1050.0000 \\
.001 \\
\text { orrelation: }\end{array}$ & \\
\hline
\end{tabular}

about 31 percent to age. When these factors were considered simultaneously, the effect of sex upon PI scores was reduced essentially to zero.

About the same result was had when the analysis was repeated for a subsample of individuals who had received biochemical as well as physical examinations. This analysis is shown in Table 7. About the same percentage of variance in PI scores is explained, and the principal concomitant factors were age, oral debris, and calculus. When considered simultaneously with these factors, there was little remaining effect attributable to hemoglobin, hematocrit, serum ascorbic acid, serum vitamin $A$, serum carotene, urinary thiamine, urinary riboflavin, urinary N'Methylnicotinamide, the classical physical signs of malnutrition, or place and condition of residence.

Advantages and disadvantages. One principal disadvantage of indices of this type has already been mentioned-the fact that an index figure is an abstraction, without meaning to the person not familiar with its bases and computation. The second disadvantage is common to most field methods used in the study of oral disease: the flat necessity that examiners be calibrated directly to each other if quantitative comparison is to be attempted between their findings.

As for advantages, I think we have shown that PI data can be precise, and that the method has proved useful in the hands of a large number of people. Perhaps the greatest value of PI is the great volume of information generated through its use. Population PI data have been reported from such widespread areas as Alaska, Ethiopia, Peru, Ecuador, Vietnam, Chile, Colombia, Thailand, Lebanon, the West Indies, Uruguay, Burma, Jordan, Bolivia, Malaya, Northeast Brazil, Nigeria, the Sudan, Iran, Ceylon, India, Iceland, Taiwan, Australia, Norway, New Zealand, Israel, Egypt, and the United States. ${ }^{7}$ One set of 
data from the United States is unique in that it presents PI scores and associated data for an area probability sample of the entire nation. ${ }^{3}$ These findings are, and probably will be for many years to come, the principal baseline for periodontal disease in North America.
In short, then, PI is here; it has been used widely; it works; and through its use we have gained a considerable insight into the population characteristics of periodontal disease.

\section{REFERENCES}

\begin{abstract}
1. Dental health. pp. 175-98. (in: Nutrition Section, Office of International Research, National Institutes of Halth. Republic of Nigeria nutrition survey. Washington, Public Health Service, March 1967. xxvi +299 p.)

2. Greene, J. C. and Vermillion, J. R.: The simplified oral hygiene index. Am. Dent. A. J., 68:7-13, Jan. 1964.

3. Kelly, J. E. and Van Kirk, L. E.: Periodontal disease in adults, United States, 1960-1962. National Center for Health Statistics Series 11, No. 12. Washington, U. S. Public Health Service, Nov. 1965. 30 p.

4. Russell, A. L.: A system of classification and scoring for prevalence surveys of periodontal disease. $J$. Dent. Res., 35:350-9, June 1956.

5. Russell, A. L.: International nutrition surveys: a summary of preliminary dental findings. J. Dent. Res., 42:233-44, Jan.-Feb. 1963.
\end{abstract}

6. Russell, A. L.: World epidemiology and oral health. pp. 21-39. (in: Kreshover, S. J., and McClure, F. J., editors. Environmental variables in oral disease. Washington, American Association for the Advancement of Science, 1966. xii +311 p.)

7. Russell, A. L.: Epidemiology of periodontal disease. Int. Dent. J., 17:282-96, June 1967.

8. Russell, A. L. and Ayers, Polly: Periodontal disease and socioeconomic status in Birmingham, Ala. Am. J. Pub. Health, 50:206-14, Feb. 1960.

9. Russell, A. L., Leatherwood, E. C., Consolazio, C. F. and Van Reen, Robert: Periodontal disease and nutrition in South Vietnam. J. Dent. Res., 44:775-82, July-Aug. 1965.

10. Sandler, H. C., and Stahl, S. S.: The influence of generalized diseases on clinical manifestations of periodontal disease. Am. Dent. A. J., 49:656-71, Dec. 1954. 